\title{
Current status of multiple antigen-presenting peptide vaccine systems: Application of organic and inorganic nanoparticles
}

Yoshio Fujita* and Hiroaki Taguchi

\begin{abstract}
Many studies are currently investigating the development of safe and effective vaccines to prevent various infectious diseases. Multiple antigen-presenting peptide vaccine systems have been developed to avoid the adverse effects associated with conventional vaccines (i.e., live-attenuated, killed or inactivated pathogens), carrier proteins and cytotoxic adjuvants. Recently, two main approaches have been used to develop multiple antigenpresenting peptide vaccine systems: (1) the addition of functional components, e.g., T-cell epitopes, cell-penetrating peptides, and lipophilic moieties; and (2) synthetic approaches using size-defined nanomaterials, e.g., selfassembling peptides, non-peptidic dendrimers, and gold nanoparticles, as antigen-displaying platforms. This review summarizes the recent experimental studies directed to the development of multiple antigen-presenting peptide vaccine systems.
\end{abstract}

\section{Introduction}

From the latter half of the $18^{\text {th }}$ century onwards, vaccinations have saved millions of human lives and countless animals, and vaccinology contributes to the prevention of infectious diseases (e.g., polio, measles, and rubella) and antiserums for toxoids (e.g., snake bites, spider bites and jellyfish stings). However, there is a strong demand for the development of safer and more effective vaccines toward not only the prevention of many infectious diseases, e.g., human immunodeficiency virus (HIV) [1-3], malaria [4-6], group A streptococci (GAS) $[7,8]$, hepatitis $\mathrm{C}$ virus (HCV) $[9,10]$, and severe acute respiratory syndrome (SARS) [11,12], but also for cancer immunotherapy [13-15]. Synthetic immunogenic peptides are ideal vaccine subunit components because of the following differences to traditional vaccines composed of live-attenuated, killed or inactivated pathogens e.g., bacteria or viruses: (1) no infectious material; (2) no cross-reactivity with host tissues; (3) induction of sitespecific antibodies (Abs); (4) ability to chemically define and modify products; and (5) swift large-scale manufacturing and long-term storage in the event of a

\footnotetext{
* Correspondence: yfujita@suzuka-u.ac.jp

Faculty of Pharmaceutical Sciences, Suzuka University of Medical Science, 3500-3, Minami-Tamagaki, Suzuka 513-8670, MIE, Japan
}

pandemic. However, the biological activity of peptides is generally short due to enzymatic degradation, and small peptides that are used as antigens are not recognized by immune cells, e.g., dendritic cells (DCs) and macrophages, and do not elicit a strong immune response when administered alone. The co-administration of adjuvants (e.g., water-in-oil emulsions, oil-in-water emulsions, liposomes, bacterial lipophilic compounds, etc.) with subunit peptide antigens is one of the methods used to enhance the immune response; however, only a few adjuvants are approved for clinical use [16]. Alternatively, short antigenic peptides induce strong immune responses when co-administrated or engaged with carrier proteins (e.g., ovalbumin (OVA), bovine serum albumin, keyhole limpet hemocyanin, tetanus toxoid, etc.); however, they are also associated with undesirable effects such as the suppression of the antipeptide $\mathrm{Ab}$ response and the production of Abs against the carrier proteins [17-22].

Tam developed the multiple antigenic peptide (MAP) system to improve the poor immunogenicity of subunit peptide vaccines [23]. In this MAP system, multiple copies of antigenic peptides are simultaneously bound to the $\alpha$ - and $\varepsilon$-amino groups of a non-immunogenic Lys-based dendritic scaffold (Figure 1). The proteinsized MAP molecules acquire stability from enzymatic 


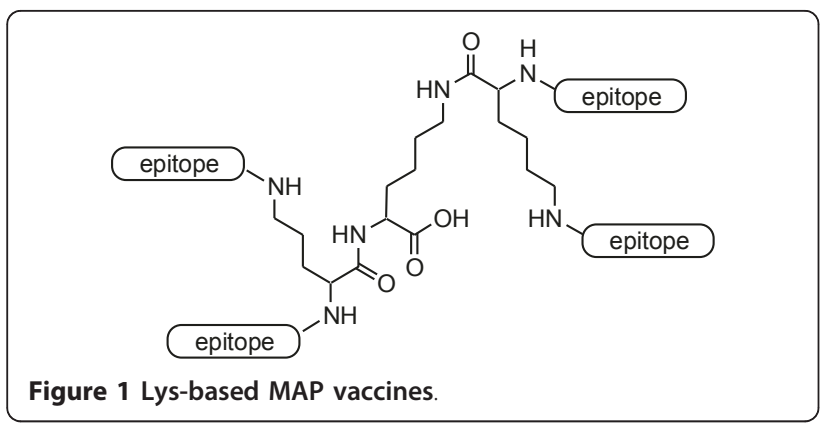

degradation, enhanced molecular recognition by immune cells, and induction of stronger immune responses compared with small antigenic peptides. The MAP concept represented a major breakthrough for vaccine systems and further improvements in a large variety of multiple antigens-presenting peptide vaccine systems have been investigated. This review focuses on the current status of multiple antigen-presenting vaccine approaches, especially the addition of functional components and the application of a wide variety of synthetic methods and size-defined nanomaterials, e.g., self-assembling peptides, dendrimers and gold nanoparticles, as antigen-displaying platforms.

\section{Functional components}

Tam's MAP vaccines that carried several copies of peptide antigens on a Lys-based dendrimer induced higher $\mathrm{Ab}$ production than single peptide monomers and carrier protein-peptide conjugates; however, additional components, such as an adjuvant, were required in many cases. Therefore, great efforts have been directed toward improvement of these MAP vaccines by the incorporation of various functions into a single vaccine molecule using helper T-cell epitopes, immune-stimulant lipid moieties, or cell-penetrating peptides have been conducted.

\section{(1) Helper T-cell epitope}

Antigens are taken up by antigen-presenting cells (APCs) and B-cells and undergo proteolysis to form peptide epitopes. Of them, T-cell epitopes are presented by class II molecules of the major histocompatibility complex (MHC) on the surface of APCs and B-cells. APCs activate helper T-cells by the interaction between the $\mathrm{T}$-cell receptors on $\mathrm{T}$-cells and the epitopes/MHC class II complexes on the surface of APCs. The activated helper T-cells recognize B-cells that have the same epitopes/MHC II complexes on their surfaces. This T-cell/ $\mathrm{B}$-cell interaction is the trigger for the differentiation of B-cells into plasma cells that secrete Abs. The use of certain $\mathrm{T}$-cell epitopes induces strong immune responses, and carrier proteins are used as a source of helper T-cell epitopes. Subunit peptide vaccines containing only B-cell epitopes cannot always elicit strong immune responses due to a lack of $\mathrm{T}$-cell activation.

The incorporation of helper T-cell epitopes into MAP vaccines has been investigated [22,24]. MAP vaccines containing B- and T-cell epitopes in a single construct induced strong immune responses and have been studied in clinical trials [25]. Although single vaccine molecules containing $\mathrm{B}$ - and $\mathrm{T}$-cell epitopes induced the production of Abs against the defined T-cell epitopes, in some cases, the $\mathrm{Ab}$ titers of the anti-T-cell epitopes were mostly lower than those of B-cell epitopes [26,27].

\section{(2) Lipophilic modifications}

A wide variety of cells including B-cells, T-cells, DCs, and macrophages express Toll-like receptors (TLRs) on their surfaces. Eleven TLRs (named simply TLR-1 to TLR-11) in human have been identified to date [28]. TLRs are a family of pattern-recognition receptors that recognize structural components of many bacteria, viruses and fungi, and play a critical role in the early innate immune response. TLR-mediated stimulation of APCs significantly enhances the secretion of pro-inflammatory cytokines, $\mathrm{Ab}$ production, and immune responses and, TLR agonists may be able to be used in alternative adjuvant systems.

Bacterial lipid components such as Pam3Cys (the inner and outer membrane components of gram-negative bacteria) $[29,30]$, and Pam2Cys (the lipid component of macrophage-activating lipopeptide 2 isolated from mycoplasma) [31,32] as well as synthetic $\alpha$-lipo amino acids [33,34] are characterized as TLR-2 agonists and used as immune-stimulating lipophilic moieties (Figure 2) that are attached to antigenic peptides (lipopeptides). Other lipophilic compounds such as $O$-acyl serine, $N$-acyl lysine and glycolipids are also utilized for this purpose [35-37]. Lipopeptides stimulate innate immunity by their interaction with TLRs on DCs, [38-42] and elicit long-lasting systemic immune responses and T-cell proliferations [43-45], resulting in the enhanced immunogenicity of unmodified peptides by more than a few orders of magnitude. In addition, lipopeptides show none of the harmful side effects of adjuvants. Lipopeptide vaccines are currently in pre-clinical and clinical trials treating HIV and hepatitis B virus [46-48]. The incorporation of lipids with known immune-stimulating characteristics into the MAP system produces self-adjuvanting lipopeptide vaccine candidates that can induce $\mathrm{Ab}$ and cellular responses in the absence of additional adjuvants [33,49-52].

\section{(3) Cell-penetrating peptides}

Since the discovery of the cellular membrane translocating property of the human immunodeficiency virus transactivating regulatory protein (HIV TAT), several peptides with the ability to translocate to the plasma 


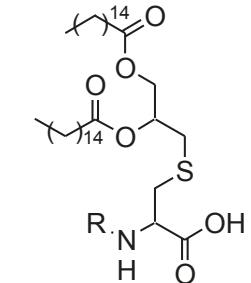

Pam3Cys: $\mathrm{R}=$ Y لll

Pam2Cys: $\mathrm{R}=\mathrm{H}$

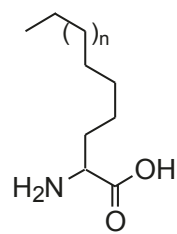

lipo amino acids

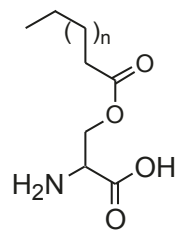

O-acyl Ser

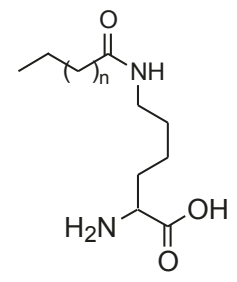

$N$-acyl Lys

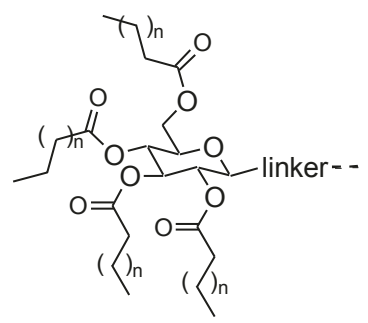

glycolipids

Figure 2 Structure of immune-stimulating lipid moieties.

membrane have been identified and named as cell-penetrating peptides (CPPs). CPPs have been studied for their ability to deliver peptides/proteins [53,54], oligonucleotides/DNA/RNA [55-58], and even much bigger molecules such as liposomes $[59,60]$ into the cytoplasm of cells. Fully exploiting this ability, CPPs are being utilized in vaccine studies for the delivery of antigens to APCs with the aim of antigen presentation and the induction of an immune response [61,62]. CPP-antigen conjugates enhance the cross-penetration of antigens into DCs $[63,64]$; however, CPPs function in all cell types, and a dual functionalized compound (CPP conjugation and DC targeting) that was designed in one study showed no synergistic enhancement of the immune response [65].

As such, numerous attempts to incorporate various functional components into single molecules have been performed. One consideration for the design of multiple antigen-presenting vaccines composed of various components is their molecular geometry, i.e., altering the linkage and spatial arrangement of each component evidently influences the conformational structure (lack of $\alpha$-helicity), solubility, and molecular recognition by immune cells [27,66-71]. Zeng et al. studied the influence of diverse chemical linkages and epitope orientations on immunological activity [27]. Either N-terminus or C-terminus of both T-cell epitope and B-cell epitope were linked via disulfate, thioether, oxime, or peptide bond. The immunological evaluation of the same epitope-containing molecules with different linkages showed unique properties in terms of their stabilities to serum and the ability to induce Abs against T-cell and/ or B-cell epitopes. Abdel-Aal et al. studied the relationship between immunological activity and the structural arrangement of multiple antigens-presenting vaccine molecules with 3 components (J14 as a B-cell epitope, P25 as a CD $4^{+}$T-cell epitope, and $\alpha$-lipo amino acids), showing clearly that changing the position of each component significantly affected the production of IgG Abs against B-cell epitopes and, in some cases, T-cell epitopes [66].

\section{Structural platforms and enabling chemistry}

In the case of the MAP systems, the number of peptide epitopes that can be incorporated into a Lys-based dendritic scaffold is limited. Furthermore, stepwise solid phase peptide synthesis (SPPS) of branching peptides such as MAPs commonly encounters the difficulty of purification to homogeneity and characterization of the final products. Using purified short peptides as building blocks, several chemoselective conjugation techniques $(e$. g., native chemical ligation [52], thioether ligation $[72,73]$, thiazolidine/oxazolidine ligation [74], oxime ligation [75], maleimide [76], and $\mathrm{Cu}(\mathrm{I})$-catalyzed azidealkyne cycloaddition [77]) have been applied to the synthesis of multiple antigen-presenting vaccines; however, the difficulties associated with the stoichiometrical stepwise incorporation of many of the same or different peptide epitopes into Lys-based dendritic scaffolds remain $[73,78-80]$. Concerning the design, preparation and biological activity of multiple antigen-presenting vaccine molecules, the stoichiometric epitope density of multivalent ligands is an important parameter $[81,82]$. Hence, we now introduce the alternative synthetic approaches that are used to attach multiple copies of antigenic peptides onto organic or inorganic scaffolds instead of a Lys-based dendrimer.

\section{(1) Radical-induced polymerization}

Polymer chemistry using purified antigenic peptides is suitable to prepare multiple antigen-presenting vaccine molecules. Free radical-induced polymerization of vinyl monomers is one of the most common and useful reactions for making polymers. An acryloyl $\left(\mathrm{CH}_{2}=\mathrm{CHCO}-\right)$ group, as a key functional group for polymerization, can easily be introduced into peptides during conventional SPPS. Free radical-induced polymerization of acryloylpeptide building blocks yields polymeric immunogens bearing hundreds of the same or different peptide 
epitopes attached to the alkane backbone (Figure 3) [83-86]. The size of the polymer construct and the distance between individual peptidic components can be controlled by the addition of acrylamide or its analog along with chain transfer agents (dithiothreitol or mercaptoacetic acid) during the polymerization process [85].

Jackson et al. evaluated the vaccine efficacy of polymeric immunogens containing 7 B-cell epitopes $(88 / 30$, Y504S, BSA10, NS27, NS1, NS5, and PL1; the N-terminal GAS M protein sequences) and the chimeric peptide J14 (a B-cell epitope consisting of the GAS Mprotein $\mathrm{C}$-region and GCN4 DNA-binding protein sequence). The polymeric GAS vaccine molecules showed outstanding broad immunogenicity and protection from GAS infection in mice. Abs against each of the individual epitopes presented in the polymers were successfully elicited [86].

\section{(2) Self-assembling nanoparticles as antigen-presenting platforms}

Peptides with certain helical or $\beta$-hairpin/sheet secondary structures can assemble themselves to form tubular, fibrillar, or spherical structures on the nano-scale via non-covalent interactions (e.g., van der Waals bonds, electrostatic interactions, hydrogen bonds or stacking interactions). They are called self-assembling peptides and applied as topologically defined building blocks in various fields including material sciences, molecular electronics, tissue engineering, and drug delivery [87-89]. The ability of these self-assembling peptides to form nanostructures is also of great interest for a repetitive antigen display system (Figure 4).

Burkhard's group used self-assembling peptide nanoparticles composed of a pentameric coiled-coil oligomerization domain derived from cartilage oligomeric matrix protein [90] and a de novo trimeric coiled-coil oligomerization domain [91] as multiple antigen-display

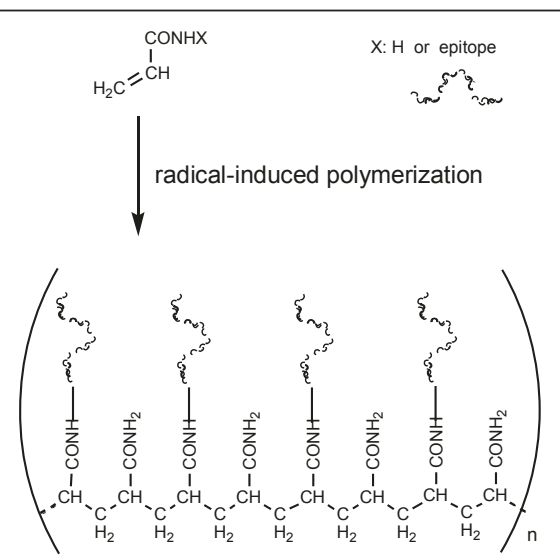

Figure 3 Vaccine molecules presenting a number of epitopes on alkyl backbone formed by free radical-induced polymerization of acryloyl groups.

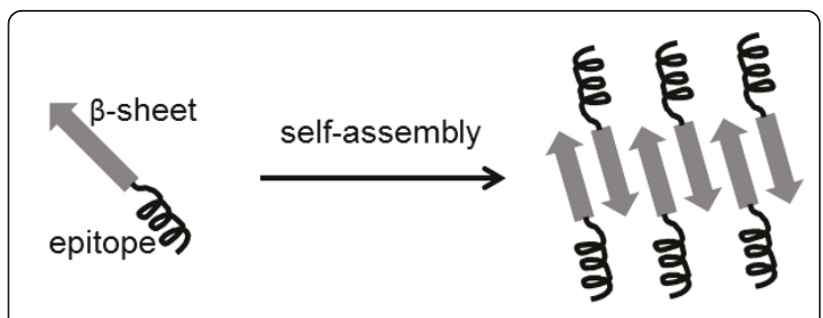

Figure 4 Systematic self-assembling peptide vaccine with repetitive antigens.

platforms [71,82]. An $\alpha$-helical coiled-coil B-cell epitope HRC1, derived from the SARS S protein, was then attached on the self-assembling peptide nanoparticles. Self-assembly in phosphate-buffered saline yielded nanoparticles ( $25 \mathrm{~nm}$ in diameter) that exposed multiple copies of HRC1 on their surface. Circular dichroism (CD) spectra indicated that the peptide nanoparticles maintain an $\alpha$-helical conformation. Immunological evaluation of the nanoparticles containing HRC1 showed specific $\mathrm{Ab}$ production and moderate neutralization activity of SARS coronavirus infectivity [71]. Furthermore, immunization of mice with peptide nanoparticles bearing the malaria B-cell epitope (DPPPPNPN) ${ }_{2} \mathrm{D}$ successfully induced high $\mathrm{Ab}$ titers and long-lasting protection. The majority of these mice were protected against an initial challenge of parasites for up to 6 months after the last immunization or up to 15 months against a second challenge [82]. This self-assembling peptide nanoparticle vaccine against Malaria is currently undergoing pre-clinical trial in the US.

A short fibrillizing peptide Q11 self-assembles in a salt-containing aqueous solution to form networks of $\beta$ sheet-rich nanofibers with a width of $15 \mathrm{~nm}$; and the resulted nanoparticles are non-cytotoxic and minimally immunogenic [92,93]. Rudra et al. used Q11 as a multiple antigen-presenting vaccine system. Self-assembling peptide nanofibers (O-Q11), in which the $\mathrm{OVA}_{323-339}$ epitope, derived from chicken egg OVA, and Q11 were linked via a spacer, were subcutaneously administrated into mice and elicited high IgG titers in the absence of an additional adjuvant. The Ab titers were remarkably higher compared with the admixture of $\mathrm{OVA}_{323-339}$ and complete Freund's adjuvant (CFA). According to this study, Ab titers against Q11 were not determined even when it was co-administrated with CFA [94].

The usage of a self-assembling non-peptidic dendritic polymer as an antigen-display system was recently reported. Multiple copies of J14 (B-cell epitope from the GAS M-protein) were attached on dendrimers via $\mathrm{Cu}(\mathrm{I})$ catalyzed azide-alkyne cycloaddition and the subsequent self-assembly was carried out in water to form nanoparticles (20 nm in diameter). After subcutaneous immunization with the J14-bearing nanomolecules, several 


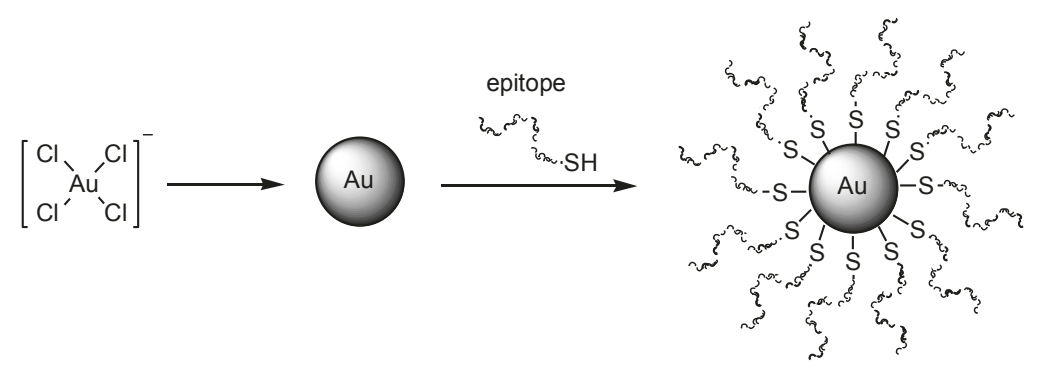

Figure 5 Multiple antigens-presenting gold nanoparticle vaccines.

subclasses of IgG were successfully produced without any adjuvants [77].

\section{(3) Gold nanoparticles as antigen carriers}

As an alternative to organic compounds (certain peptides or polymers), inorganic materials such as $\mathrm{SiO}_{2}$, $\mathrm{Ag}, \mathrm{Pt}$, and $\mathrm{Au}$ are also known to form nanoparticles. Colloidal gold nanoparticles (GNPs) are of interest for various biomedical applications [95,96], e.g., imaging [97-99], photo-activated therapeutics [100], tumor detection [101], and drug delivery [102-104] as well as multivalent antigen carrier scaffoldings [105-107] instead of conventional carrier proteins and synthetic dendrimers/polymers. GNPs are an ideal material primarily because of their biocompatibility and lack of immunogenicity $[108,109]$. GNPs can be easily prepared from gold salt $\left(\mathrm{H}\left[\mathrm{AuCl}_{4}\right]\right)$ in water and their particle sizes are controllable (ranging from 1-100 nm in diameter) [110-113]; consequently, gold surface electrodes can be readily reacted with molecules bearing a mercapto $(\mathrm{SH})$ group (Figure 5$)$. The strong attachment between the mercapto group and the gold surface is easily prepared as well as the chemoselective conjugation, e.g., native chemical ligation, click chemistry, oxime ligation, and thioether ligation [52,72-77] of the antigenic peptide and synthetic core particles (sophisticated in some cases). The sizedependent toxicity of naked GNPs can be reduced by modifying their surfaces [114]. The intracellular uptake of GNPs is mediated through endocytosis [115-117], enabling GNPs to deliver the attached molecules into the cell. GNP-peptide conjugates resistant to enzymatic and lysosomal degradation. As such, GNPs are suitable materials to use as antigenpresenting scaffolds.

Chen et al. demonstrated that the addition of extra Cys residues to the $\mathrm{C}$-terminus of an epitope, derived from the VP1 protein of the foot-and-mouth disease virus, allowed its conjugation to different sized GNPs as antigen carriers. Mice that were immunized with these GNP-epitope conjugates showed significant size-dependent immunogenicity and biodistribution in the spleen [107].
Conjugation with the Fc fragment from human IgG targeting the $\mathrm{Fc} \gamma$ receptor on human DCs into GNPs successfully enhanced the cellular uptake of antigens. In addition, GNP-epitope-Fc conjugates showed better antigen-uptake activity, immunological responses and lymphocyte proliferation compared with the use of liposomes as an antigen-delivery system [118].

\section{Conclusion}

The current status of multiple antigens-presenting vaccine systems has been reviewed. Various functional components ( $T$-helper epitopes, immune-stimulating lipids, and cell-penetrating peptides) have been attached with antigens to improve subunit peptide vaccine potentiation, such as the effective and selective activation of a particular immune system and mucosal immunity. Meanwhile, the recent use of size-defined organic and inorganic nanomaterials without either immunogenicity or cytotoxicity as antigen-display platforms surely advances the development of subunit peptide vaccines without the use of adjuvants. Each of these nanomaterials as antigen-display platforms, however, has shortcomings such as requirement of several synthetic steps and cost. Optimization of the balance between vaccine efficacy and the amounts or ratio of attached B-epitopes and additional functional components, and exploring alternative safe and economical materials for multiple antigen-presenting systems instead of Au would help reduce the cost for their practical use. As the optimization of the balance continues to investigate, antigen-display platforms would be an ideal component to develop vaccines.

\section{Acknowledgements}

This work was supported by Grants-in-Aid for Young Scientists (B) from the Ministry of Education, Culture, Sports, Science and Technology in Japan to YF (23790144)

\section{Authors' contributions}

YF drafted the manuscript. HT helped to draft the manuscript. All authors read and approved the final manuscript.

\section{Competing interests}

The authors declare that they have no competing interests. 
Received: 28 February 2011 Accepted: 23 August 2011

Published: 23 August 2011

\section{References}

1. Kim JH, Rerks-Ngarm S, Excler JL, Michael NL: HIV vaccines: lessons learned and the way forward. Curr Opin HIV AIDS 2010, 5(5):428-434.

2. Voronin $Y$, Manrique A, Bernstein A: The future of HIV vaccine research and the role of the Global HIV Vaccine Enterprise. Curr Opin HIV AIDS 2010, 5(5):414-420.

3. Vaccari M, Poonam P, Franchini G: Phase III HIV vaccine trial in Thailand: a step toward a protective vaccine for HIV. Expert Rev Vaccines 2010, 9(9):997-1005.

4. Genton B: Malaria vaccines: a toy for travelers or a tool for eradication? Expert Rev Vaccines 2008, 7(5):597-611.

5. Garcia LS: Malaria. Clin Lab Med 2010, 30(1):93-129.

6. Kappe SH, Vaughan AM, Boddey JA, Cowman AF: That was then but this is now: malaria research in the time of an eradication agenda. Science 2010, 328(5980):862-866

7. Dale JB: Current status of group A streptococcal vaccine development. Adv Exp Med Biol 2008, 609:53-63.

8. Steer AC, Batzloff MR, Mulholland K, Carapetis JR: Group A streptococcal vaccines: facts versus fantasy. Curr Opin Infect Dis 2009, 22(6):544-552.

9. Yu Cl, Chiang BL: A new insight into hepatitis C vaccine development. J Biomed Biotechnol 2010, 2010:548280.

10. Stoll-Keller F, Barth H, Fafi-Kremer S, Zeisel MB, Baumert TF: Development of hepatitis $C$ virus vaccines: challenges and progress. Expert Rev Vaccines 2009, 8(3):333-345.

11. Du L, He Y, Zhou Y, Liu S, Zheng BJ, Jiang S: The spike protein of SARSCoV-a target for vaccine and therapeutic development. Nat Rev Microbiol 2009, 7(3):226-236

12. Roper RL, Rehm KE: SARS vaccines: where are we? Expert Rev Vaccines 2009, 8(7):887-898

13. Sundaram R, Dakappagari NK, Kaumaya PT: Synthetic peptides as cancer vaccines. Biopolymers 2002, 66(3):200-216.

14. Oka Y, Tsuboi A, Fujiki F, Li Z, Nakajima H, Hosen N, Shirakata T, Nishida S, Oji Y, Kawase I, Sugiyama H: WT1 peptide vaccine as a paradigm for "cancer antigen-derived peptide"-based immunotherapy for malignancies: successful induction of anti-cancer effect by vaccination with a single kind of WT1 peptide. Anticancer Agents Med Chem 2009, 9(7):787-797.

15. Carballido E, Fishman M: Sipuleucel-T: prototype for development of antitumor vaccines. Curr Oncol Rep 2011, 13(2):112-9.

16. Heegaard PMH, Dedieu L, Johnson N, Le Potier M-F, Mockey M, Mutinelli F, Vahlenkamp T, Vascellari M, Sørensen NS: Adjuvants and delivery systems in veterinary vaccinology: current state and future developments. Arch Virol 2010, 156(2):183-202.

17. Herzenberg $L A$, Tokuhisa $T$, Herzenberg A: Carrier-priming leads to hepten-specific suppression. Nature 1980, 285(5767):664-667.

18. Landsteiner K: The Specificity of Serological Reactions. Harvard Univ Press, Cambridge, MA; 31962.

19. Avery OT, Goebel WF: Chemo-immunological studies on conjugated carbohydrate protein: $\mathrm{V}$. the immunological specificity of an antigen prepared by combining the capsular polysaccharide of type III pneumococcus with foreign protein. J Exp Med 1931, 54(3):437-447.

20. Schutze MP, Leclerc C, Jolivet M, Audibert F, Chedid L: Carrier-induced epitopic suppression, a major issue for future synthetic vaccines. J Immunol 1985, 135(4):2319-2322.

21. DiJohn D, Wasserman SS, Torres JR, Cortesia MJ, Murillo J, Losonsky GA, Herrington DA, Stürchler D, Levine MM: Effect of priming with carrier on response to conjugate vaccine. Lancet 1989, 2(8677):1415-1418.

22. Kumar A, Arora R, Kaur P, Chauhan VS, Sharma P: "Universal" T helper cell determinants enhance immunogenicity of a Plasmodium falciparum merozoite surface antigen peptide. J Immunol 1992, 148(5):1499-1505.

23. Tam JP: Synthetic peptide vaccine design: synthesis and properties of a high-density multiple antigenic peptide system. Proc Natl Acad Sci USA 1988, 85(15):5409-5413.

24. Etlinger HM, Knorr R: Model using a peptide with carrier function for vaccination against different pathogens. Vaccine 1991, 9(7):512-514.

25. Nardin EH, Oliveira GA, Calvo-Calle JM, Castro ZR, Nussenzweig RS, Schmeckpeper B, Hall BF, Diggs C, Bodison S, Edelman R: Synthetic malaria peptide vaccine elicits high levels of antibodies in vaccinees of defined HLA genotypes. J Infect Dis 2000, 182(5):1486-1496.

26. Ghosh S, Jackson DC: Antigenic and immunogenic properties of totally synthetic peptide-based anti-fertility vaccines. Int Immunol 1999, 11(7):1103-1110.

27. Zeng W, Ghosh S, Macris M, Pagnon J, Jackson DC: Assembly of synthetic peptide vaccines by chemoselective ligation of epitopes: influence of different chemical linkages and epitope orientations on biological activity. Vaccine 2001, 19(28-29):3843-3852.

28. Bhattacharjee RN, Akira S: Toll-like receptor signaling: emerging opportunities in human diseases and medicine. Curr Immunol Rev 2005, 1(1):81-90.

29. Huang W, Nardelli B, Tam JP: Lipophilic multiple antigen peptide system for peptide immunogen and synthetic vaccine. Mol Immunol 1994, 31(15):1191-1199.

30. Zeng W, Jackson DC, Murray J, Rose K, Brown LE: Totally synthetic lipidcontaining polyoxime peptide constructs are potent immunogens. Vaccine 2000, 18(11-12):1031-1039.

31. Lau YF, Deliyannis G, Zeng W, Mansell A, Jackson DC, Brown LE: Lipidcontaining mimetics of natural triggers of innate immunity as CTLinducing influenza vaccines. Int Immunol 2006, 18(12):1801-1813.

32. Mühlradt PF, Kiess $M$, Meyer $H$, Süssmuth $R$, Jung $G$ : Isolation, structure elucidation, and synthesis of a macrophage stimulatory lipopeptide from Mycoplasma fermentans acting at picomolar concentration. J Exp Med 1997, 185(11):1951-1958.

33. Horváth A, Olive C, Wong A, Clair T, Yarwood P, Good M, Toth I: Lipoamino acid-based adjuvant carrier system: enhanced immunogenicity of group A streptococcal peptide epitopes. J Med Chem 2002, 45(6):1387-1390.

34. Zaman M, Abdel-Aal A-BM, Phillipps KSM, Fujita Y, Good MF, Toth I: Structure-activity relationships of lipopeptide group A streptococcus (GAS) vaccine candidates on toll-like receptor 2. Vaccine 2010, 28(10):2243-2248.

35. Fujita Y, Abdel-Aal AB, Wimmer N, Batzloff MR, Good MF, Toth I: Synthesis and immunological evaluation of self-adjuvanting glycolipopeptide vaccine candidates. Bioorg Med Chem 2008, 16(19):8907-8913.

36. Hopp TP: Immunogenicity of a synthetic HBSAG peptide - enhancement by conjugation to a fatty-acid carrier. Mol Immunol 1984, 21(1):13-16.

37. Deres $\mathrm{K}$, Schild $\mathrm{H}$, Wiesmüller $\mathrm{KH}$, Jung $\mathrm{G}$, Rammensee $\mathrm{HG}$ : In vivo priming of virus-specific cyto-toxic lymphocytes-T with synthetic lipopeptide vaccine. Nature 1989, 342(6249):561-564.

38. Loing E, Andrieu M, Thiam K, Schörner D, Wiesmüller KH, Hosmalin A, Jung $G$, Gras-Masse H: Extension of HLA-A*0201-restricted minimal epitope by $N^{\varepsilon}$-palmitoyl-lysine increases the life span of functional presentation to cytotoxic T cells. J Immunol 2000, 164(2):900-907.

39. Zeng W, Ghosh S, Lau YF, Brown LE, Jackson DC: Highly immunogenic and totally synthetic lipopeptides as self-adjuvanting immunocontraceptive vaccines. J Immunol 2002, 169(9):4905-4912.

40. Jackson DC, Lau TF, Le T, Suhrbier A, Deliyannis G, Cheers C, Smith C, Zeng $W$, . Brown LE: A totally synthetic vaccine of generic structure that targets Toll-like receptor 2 on dendritic cells and promotes antibody or cytotoxic T cell responses. Proc Natl Am Soc 2004, 101(43):15440-15445.

41. Chua BY, Healy A, Cameron PU, Stock O, Rizkalla M, Zeng W, Torresi J, Brown LE, Fowler NL, Gowans EJ, Jackson DC: Maturation of dendritic cells with lipopeptides that represent vaccine candidates for hepatitis $C$ virus. Immunol Cell Biol 2003, 81(1):67-72.

42. Zhu X, Ramos TV, Gras-Masse H, Kaplan BE, BenMohamed L: Lipopeptide epitopes extended by an $N^{\varepsilon}$-palmitoyl-lysine moiety increase uptake and maturation of dendritic cells through a Toll-like receptor-2 pathway and trigger a Th1-dependent protective immunity. Eur I Immunol 2004, 34(11):3102-3114.

43. Langhan B, Braunschweiger I, Schweitzer S, Jung G, Inchauspé G, Sauerbruch T, Spengler U: Lipidation of T helper sequences from hepatits C virus core significantly enhances T-cell activity in vitro. Immunol 2001, 102(4):460-465.

44. Rouaix F, Gras-Masse H, Mazingue C, Diesis E, Ridel PR, Estaquier J, Capron A, Tartar A, Auriault C: Effect of a lipopeptidic formulation on macrophage activation and peptide presentation to T cells. Vaccine 1994, 12(13):1209-1214.

45. BenMohamed L, Gras-Masse H, Tartar A, Daubersies P, Brahimi K, Bossus M, Thomas A, Druilhe P: Lipopeptide immunization without adjuvant induces potent and long-lasting $B, T$ helper, and cytotoxic $T$ lymphocyte 
responses against a malaria liver stage antigen in mice and chimpanzees. Eur J Immunol 1997, 27(5):1242-1253.

46. Pialoux G, Gahéry-Ségard H, Sermet S, Poncelet H, Fournier S, Gérard L, Tartar A, Gras-Masse H, Levy JP, Guillet JG, ANRS VAC 04 Study Team: Lipopeptides induce cell-mediated anti-HIV immune responses in seronegative volunteers. AIDS 2001, 15(10):1239-1249.

47. Livingston BD, Crimi C, Grey H, Ishioka G, Chisari FV, Fikes J, Grey H, Chesnut RW, Sette A: The hepatitis B virus-specific CTL responses induced in humans by lipopeptide vaccination are comparable to those elicited by acute viral infection. J Immunol 1997, 159(3):1383-1392.

48. Salmon-Céron D, Durier C, Desaint C, Cuzin L, Surenaud M, Hamouda NB, Lelièvre JD, Bonnet B, Pialoux G, Poizot-Martin I, Aboulker JP, Lévy Y, Launay O, ANRS VAC18 trial group: Immunogenicity and safety of an HIV1 lipopeptide vaccine in healthy adults: a phase 2 placebo-controlled ANRS trial. AIDS 2010, 24(14):2211-2223.

49. Defoort JP, Nardelli B, Huang W, Ho DD, Tam JP: Macromolecular assemblage in the design of a synthetic AIDS vaccine. Proc Natl Acad SoC USA 1992, 89(9):3879-3883.

50. Defoort JP, Nardelli B, Huang W, Tam JP: A rational design of synthetic peptide vaccine with a built-in adjuvant: a modular approach for unambiguity. Int J Pept Protein Res 1992, 40(3-4):214-221.

51. Nardelli B, Haser PB, Tam JP: Oral administration of an antigenic synthetic lipopeptide (MAP-P3C) evokes salivary antibodies and systemic humoral and cellular responses. Vaccine 1994, 12(14):1335-1339.

52. Moyle PM, Hari Y, Huang N, Olive C, Good MF, Toth I: A technique for the synthesis of highly-pure, mono-epitopic, multi-valent lipid core peptide vaccines. Tetrahedron Lett 2007, 48(29):4965-4967.

53. Edenhofer F: Protein transduction revisited: novel insights into the mechanism underlying intracellular delivery of proteins. Curr Pharm Des 2008, 14(34):3628-3636.

54. Wagstaff KM, Jans DA: Protein transduction: cell penetrating peptides and their therapeutic applications. Curr Med Chem 2006, 13(12):1371-1387.

55. Crombez L, Aldrian-Herrada G, Konate K, Nguyen QN, McMaster GK, Brasseur R, Heitz F, Divita G: A new potent secondary amphipathic cellpenetrating peptide for siRNA delivery into mammalian cells. Mol Ther 2009, 17(1):95-103.

56. Turner JJ, Jones S, Fabani MM, Ivanova G, Arzumanov AA, Gait MJ: RNA targeting with peptide conjugates of oligonucleotides, siRNA and PNA. Blood Cells Mol Dis 2007, 38(1):1-7.

57. Moschos SA, Jones SW, Perry MM, Williams AE, Erjefalt JS, Turner JJ, Barnes PJ, Sproat BS, Gait MJ, Lindsay MA: Lung delivery studies using siRNA conjugated to TAT(48-60) and penetratin reveal peptide induced reduction in gene expression and induction of innate immunity. Bioconjug Chem 2007, 18(5):1450-1459.

58. Meade BR, Dowdy SF: Exogenous siRNA delivery using peptide transduction domains/cell penetrating peptides. Adv Drug Deliv Rev 2007, 59(2-3):134-140.

59. Kale AA, Torchillin VP: "Smart" drug carriers: PEGylated TATp-modified pH-sensitive liposomes. J Liposome Res 2007, 17(3-4):197-203.

60. Pappalardo JS, Quattrocchi V, Langellotti C, Di Giacomo S, Gnazzo V, Olivcra V, Calamante G, Zamorano PI, Levchenko TS, Torchilin VP: Improved transfection of spleen-derived antigen presenting cells in culture using TATp-liposomes. J Control Release 2009, 134(4):41-46.

61. Brooks NA, Pouniotis DS, Sheng KC, Apostolopoulos V, Pietersz GA: A membrane penetrating multiple antigen peptide (MAP) incorporating ovalbumin CD8 epitope induces potent immune responses in mice. Biochimica Biophysica Acta 2010, 1798(12):2286-2295

62. Brooks NA, Pouniotis DS, Tang C-T, Apostolopoulos V, Pietersz GA: Cellpenetrating peptides: application in vaccine delivery. Biochimica Biophysica Acta 2010, 1805(1):25-34

63. Kim DT, Mitchell DJ, Brockstedt DG, Fong L, Nolan GP, Fathman CG, Engleman EG, Rothbard JB: Introduction of soluble proteins into the MHC class I pathway by conjugation to an HIV tat peptide. J Immunol 1997. 159(4):1666-1668.

64. Tacken PJ, Joosten B, Reddy A, Wu D, Eek A, Laverman P, Kretz-Rommel A, Adema GJ, Torensma R, Figdor CG: No advantage of cell-penetrating peptides over receptor-specific antibodies in targeting antigen to human dendritic cells for cross-presentation. J Immunol 2008, 180(11):7687-7696.

65. Shibagaki N, Udey MC: Dendritic cells transduced with protein antigens induce cytotoxic lymphocytes and elicit antitumor immunity. J Immunol 2002, 168(5):2393-2401.
66. Abdel-Aal A-BM, Zaman M, Fujita Y, Batzloff MR, Good MF, Toth I: Design of three-component vaccines against group A streptococcal infections: importance of spatial arrangement of vaccine components. J Med Chem 2010, 53(22):8041-8046

67. Abdel-Aal A-BM, Batzloff MR, Fujita Y, Barozzi N, Faria A, Simerska P, Moyle PM, Good MF, Toth I: Structure-activity relationships of a series of synthetic lipopeptide self-adjuvanting group A streptococcal vaccine candidates. J Med Chem 2008, 51(1):167-172.

68. Ni J, Powell R, Baskakov IV, DeVico A, Lewis GK, Wang L-X: Synthesis, conformation, and immunogenicity of monosaccharide-centered multivalent HIV-1 gp41 peptides containing the sequence of DP178. Bioorg Med Chem 2004, 12(12):3141-3148.

69. Lundberg $P$, Langel U: A brief introduction to cell-penetrating peptides. J Mol Recogn JMR 2003, 16(5):227-233.

70. Joliot A, Prochiantz A: Transduction peptides: from technology to physiology. Nat Cell Biol 2004, 6(3):189-196.

71. Pimentel TAPF, Yan Z, Jeffers SA, Holmes KV, Hodges RS, Burkhard P: Peptide nanoparticles as novel immunogens: design and analysis of a prototypic severe acute respiratory syndrome vaccine. Chem Biol Drug Des 2009, 73(1):53-61.

72. Mathieu MN, Wade JD, Tan Y-Y, Summers RJ, Tregear GW: Novel Strategy for the synthesis of template-assembled analogues of rat relaxin. J Pept Sci 2000, 6(5):235-242.

73. Boykins RA, Joshi M, Syin C, Dhawan S, Nakhasi H: Synthesis and construction of a novel multiple peptide conjugate system: strategy for a subunit vaccine design. Peptides 2000, 21(1):9-17.

74. Zhang L, Tam JP: Thiazolidine formation as a general and site-specific conjugation method for synthetic peptides and proteins. Anal Biochem 1996, 233(1):87-93

75. Zeng W, Jackson DJ, Rose K: Synthesis of a new template with a built-in adjuvant and its use in contructing peptide vaccine candidates through polyoxime chemistry. J Pept Sci 1996, 2(1):66-72

76. Wang L-X, Ni J, Singh S: Carbohydrate-centered maleimide cluster as a new type of templates for multivalent peptide assembling: synthesis of multivalent HIV-1 gp41 peptides. Bioorg Med Chem 2003, 11(1):159-166.

77. Skwarczynski M, Zaman M, Urbani CN, Lin I-C, Jia Z, Batzloff MR, Good MF, Monterio MJ, Toth I: Polyacrylate dendrimer nanoparticles: A selfadjuvanting vaccine delivery system. Angew Chem Int Ed 2010, 49(33):5742-5745.

78. Horváth A, Olive C, Karpati L, Sun HK, Good M, Toth I: Toward the development of a synthetic group A streptococcal vaccine of high purity and broad protective coverage. J Med Chem 2004, 47(16):4100-4104.

79. Moyle PM, Olive C, Ho M-F, Good MF, Toth I: Synthesis of a highly pure lipid core peptide based self-adjuvanting priepitopic group $\mathrm{A}$ streptococcal vaccine, and subsequent immunological evaluation. J Med Chem 2006, 49(21):6364-6370.

80. Fujita Y, Moyle PM, Hieu S, Simerska S, Toth I: Investigation towards multiepitope vaccine candidates using native chemical ligation. Biopolymers (Pept Sci) 2008, 90(5):624-632.

81. Cairo CW, Gestwicki JE, Kanai M, Kiessling LL: Control of multivalent interactions by binding epitope density. J Am Chem Soc 2002, 124(8):1615-1619.

82. Kaba SA, Brando C, Guo Q, Mitterlholzer C, Raman S, Tropel D, Aebi U, Burkhand P, Lanar DE: A nonadjuvanted polypeptide nanoparticle vaccine confers long-lasting protection against rodent malaria. J Immunol 2009, 183(11):7268-7277.

83. O'Brien-Simpson NM, Ede NJ, Brown LE, Swan J, Jackson DC: Polymerization of unprotected synthetic peptides: A view toward synthetic peptide vaccines. J Am Chem Soc 1997, 119(6):1183-1188.

84. Jackson DC, O'Brien-Simpson NM, Ede NJ, Brown LE: Free radical induced polymerization of synthetic peptides into polymeric immunogens. Vaccine 1997, 15(15):1697-1705.

85. Sadler K, Zeng W, Jackson DC: Synthesis of peptide epitope-based polymers: Controlling size and determining the efficiency of epitope incorporation. J Pept Res 2002, 60(3):150-158.

86. Brandt ER, Sriprakash KS, Hobb Rl, Hayman WA, Zeng W, Batzloff MR, Jackson DC, Good MF: New multi-determinant strategy for a group A streptococcal vaccine designed for the Australian Aboriginal population. Nat Med 2000, 6(4):455-459. 
87. Rajagopal K, Schneider JP: Self-assembling peptides and proteins for nanotechnological applications. Curr Opin Struct Biol 2004, 14(4):480-486.

88. Hartgerink JD, Granja JR, Milligan RA, Ghadiri MR: Self-assembling peptide nanotubes. J Am Chem Soc 1996, 118(1):43-50.

89. Reches M, Gazit E: Molecular self-assembly of peptide nanostructures: Mechanism of association and potential uses. Curr Nanosci 2006, 2(2):105-111.

90. Malashkevich VN, Kammerer RA, Efimov VP, Schulthess T, Engel J: The crystal structure of a five-stranded coiled coil in COMP: a prototype ion channel? Science 1996, 274(5288):761-765.

91. Burkhard P, Meier M, Lustig A: Design of a minimal protein oligomerization domain by a structural approach. Protein Sci 2000 9(12):2294-2301

92. Jung JP, Jones JL, Cronier SA, Collier JH: Modulating the mechanical properties of self-assembled peptide hydrogels via native chemical ligation. Biomterials 2008, 29(13):2143-2151.

93. Jung JP, Nagaraj AK, Fox EK, Rudra JS, Devgun JM, Collier JH: Coassembling peptides as defined matrices for endothelial cells. Biomterials 2009, 30(12):2400-2410.

94. Rudra JS, Tian YF, Jung JP, Collier JH: A self-assembling peptide acting as an immune adjuvant. Proc Natl Acad Sci USA 2010, 107(2):622-627.

95. Sperling RA, Gil PR, Zhang F, Zanella M, Parak WJ: Biological applications of gold nanoparticles. Chem Soc Rev 2008, 37(9):1896-1908.

96. Arvizo R, Bhattacharya R, Mukherjee P: Gold nanoparticles: opportunities and challenges in nanomedicine. Expert Opin Drug Deliv 2010, 7(6):753-763.

97. McKenzie F, Faulds K, Graham D: DNA functionalized gold nanoparticles as probes for double stranded DNA through triplex formation. Chem Commun 2008, 28(20):2367-2369.

98. Eck W, Craig G, Sigdel A, Gerd R, Old LJ, Tang L, Brennan MF, Allen PJ, Mason MD: PEGylated gold nanoparticles conjugated to monoclonal F19 antibodies as targeted labeling agents for human pancreatic carcinoma tissue. ACS Nano 2008, 2(11):2263-2272.

99. Loo C, Lin A Hirsch L, Lee MH, Barton J, Halas N, West J, Drezek R: Nanoshell-enable photonics-based imaging and therapy of cancer. Technol Cancer Res Treat 2004, 3(1):33-40.

100. Pissuwan D, Valenzuela SM, Cortie MB: Therapeutic possibilities of plasmonically heated gold nanoparticles. Trends Biotechnol 2006 24(2):62-67.

101. Qian X, Peng X-H, Ansari DO, Yin-Goen Q, Chen GZ, Shin DM, Yang L, Young AN, Wang MD, Nie S: In vivo tumor targeting and spectroscopic detection with surface-enhanced Raman nanoparticle tags. Nat Biotechnol 2008, 26(1):83-90.

102. Paciotti GF, Myer L, Weinreich D, Goia D, Pavel N, McLaughlin RE, Tamarkin L: Colloidal gold: a novel nanoparticle vector for tumor directed drug delivery. Drug Deliv 2004, 11(3):169-183.

103. Gibson JD, Khanal BP, Zubarev ER: Paclitaxel-functionalized gold nanoparticles. J Am Chem Soc 2007, 129(37):11653-11661.

104. Brown SD, Nativo P, Smith J-A, Stirling D, Edwards PR, Venuopal B, Flint DJ, Plumb JA, Graham D, Wheate NJ: Gold nanoparticles for the improved anticancer drug delivery of the active component of oxaliplatin. J Am Chem Soc 2010, 132(13):4678-4684.

105. Tomii A, Masugi F: Production of anti-platelet-activating factor antibodies by the use of colloidal gold as carrier. Jpn J Med Sci Biol 1991, 44(2):75-80.

106. Zhou X, Zhang X, Yu X, Zha X, Fu Q, Liu B, Wang X, Chen Y, Chen Y, Shan $Y$, Jin $Y, W u Y$, Liu J, Kong $W$, Shen J: The effect of conjugation to gold nanoparticles on the ability of low molecular weight chitosan to transfer DNA vaccine. Biomaterials 2008, 29(1):111-117.

107. Chen Y-S, Hung Y-C, Lin W-H, Huang GS: Assessment of gold nanoparticles as a size-dependent vaccine carrier for enhancing the antibody response against synthetic food-and-mouth disease virus peptide. Nanotechnol 2010, 21:195101.

108. Connor EE, Mwamuka J, Gole A, Murphy CJ, Wyatt MD: Gold nanoparticles are taken by human cells but do not cause acute cytotoxicity. Small 2005, 1(3):325-327.

109. Male KB, Lachance B, Hrapovic S, Sunahara G, Luong JH: Assessment of cytotoxicity of quantum dots and gold nanoparticles using cell-based impedance spectroscopy. Anal Chem 2008, 80(14):5487-5493.

110. Frens $\mathrm{G}$ : Controlled nucleation for the regulation of the particle size in monodisperse gold suspensions. Nature Phys Sci 1973, 214:20-22.
111. Turkevich J: Colloidal gold Part I. Historical and preparative aspects, morphology and structure. Gold Bull 1985, 18(3):86-91.

112. Perrault SD, Chan WC: Synthesis and surface modification of highly monodispersed, spherical gold nanoparticles of 50-200 nm. J Am Chem Soc 2009, 131(47):17042-17043.

113. Martin MN, Basham Jl, Chando P, Eah S-K: Charged gold nanoparticles in non-polar solvents: 10-min synthesis and 2D self-assembly. Langmuir 2010, 26(10):7410-7417.

114. Chen Y-S, Hung Y-C, Liau I, Huang GS: Assessment of the in vivo toxicity of gold nanoparticles. Nanoscale Res Lett 2009, 4(8):858-864.

115. Malugin A, Ghandehari H: Cellular uptake and toxicity of gold nanoparticles in prostate cancer cells: a comparative study of rods and spheres. J Appl Toxicol 2010, 30(3):212-217.

116. Verma A, Uzun O, Hu Y, Han H-S, Watson N, Chen S, Irvine DJ, Stellacci F: Surface-structure-regulated cell-membrane penetration by monolayerprotected nanoparticles. Nat Mater 2008, 7(7):588-595.

117. Stokes RJ, McKenzie F, McFarlane E, Ricketts A, Tetley L, Faulds K, Alexander J, Graham D: Rapid cell mapping using nanoparticles and SERRS. Analyst 2009, 134(1):170-175.

118. Cruz LJ, Rueda F, Cordobilla B, Simón L, Hosta L, Albericio F, Domingo JC: Targeting nanosystems to human DCs via Fc receptor as an effective strategy to deliver antigen for immunotherapy. Mol Pharm 2011, 8(1):104-116.

doi:10.1186/1752-153X-5-48

Cite this article as: Fujita and Taguchi: Current status of multiple antigen-presenting peptide vaccine systems: Application of organic and inorganic nanoparticles. Chemistry Central Journal 2011 5:48.

\section{Publish with ChemistryCentral and every scientist can read your work free of charge \\ "Open access provides opportunities to our colleagues in other parts of the globe, by allowing anyone to view the content free of charge."} W. Jeffery Hurst, The Hershey Company.

- available free of charge to the entire scientific community

- peer reviewed and published immediately upon acceptance

- cited in PubMed and archived on PubMed Central

- yours - you keep the copyright

Submit your manuscript here:

http://www.chemistrycentral.com/manuscript/<smiles>c1ccccc1</smiles>

ChemistryCentral 